\title{
Analysis of the Chromosomal Localization of Yeast SMC Complexes by Chromatin Immunoprecipitation
}

\author{
Vasso Makrantoni, Daniel Robertson, and Adele L. Marston
}

\begin{abstract}
A plethora of biological processes like gene transcription, DNA replication, DNA recombination, and chromosome segregation are mediated through protein-DNA interactions. A powerful method for investigating proteins within a native chromatin environment in the cell is chromatin immunoprecipitation (ChIP). Combined with the recent technological advancement in next generation sequencing, the ChIP assay can map the exact binding sites of a protein of interest across the entire genome. Here we describe astep-by step protocol for ChIP followed by library preparation for ChIP-seq from yeast cells.
\end{abstract}

Key words Chromatin immunoprecipitation, Saccharomyces cerevisiae, Schizosaccharomyces pombe, Cohesin, Condensin, Mitosis, Meiosis, Sccl, Rec8, Brnl

\section{Introduction}

Chromatin immunoprecipitation (ChIP) is a powerful method for assaying protein-DNA binding in vivo and is broadly used to estimate the density of DNA-bound proteins at specific sites in the genome. ChIP is a multistep assay and every step needs to be optimized for consistent results. Briefly, protein-DNA associations are immobilized by cross-linking with formaldehyde [1-3] before shearing the chromatin, either mechanically [4] or by enzymatic digestion [5] into DNA fragments of average size 200-500 bp. Specific cross-linked protein-DNA complexes are then isolated by immunoprecipitation using an antibody to the protein of interest. Finally, the cross-links are reversed, and the retrieved DNA is analyzed to determine the sequences bound by the protein. ChIP followed by quantitative real-time PCR (ChIP-qPCR), using specific primers, can be used to measure protein association and relative abundance at a particular genomic locus. Alternatively, ChIP can be combined with next generation sequencing (ChIP-seq) to provide a genome-wide view of protein occupancy. While ChIP-seq allows for relative protein abundance at distinct chromosomal 
addresses to be compared within a sample, differences between samples cannot be quantified without introducing a method to normalize. Typically, this involves "spike in" of a known amount of DNA or cross-linked cells from a different species, with sufficient sequence divergence from the organism of interest to allow sequencing reads to be confidently distinguished bioinformatically [6-8]. This technique, referred to as calibrated ChIP-seq, makes it possible to quantitate genome-wide changes in the distribution of an epitope tagged protein and allows for quantification of differences in occupancy between experimental samples [8]. Calibrated ChIP-seq requires that both calibration and experimental organisms carry the same epitope tag and can be immunoprecipitated by the same protocol. For this protocol we use $S$. pombe to calibrate $S$. cerevisiae, a combination that also allows us to invert the roles, that is, calibrate $S$. pombe with $S$. cerevisiae.

The ChIP method described here has been optimized for use with chromatin from two species of yeast, S. cerevisiae and S. pombe; however, it should be easy to adapt it for use with other chromatin sources. To demonstrate the robustness of our ChIP and library preparation protocols we performed ChIP against the Sccl subunit of the cohesin multiprotein complex, tagged with the 6HA epitope [9-11]. We have also used a similar protocol for the condensin subunit Brnl [12] and for the meiotic counterpart of cohesin, Rec8 [13]. Here, we outline in detail an optimized protocol for crosslinking and harvesting cells, fragmenting chromatin, immunoprecipitating the desired protein-DNA complexes, and preparing the library for sequencing on the Illumina MiniSeq platform. A schematic stepwise representation of the method is illustrated in Fig. 1.

\section{Materials}

\subsection{Yeast Strains and Growth Media}

1. Haploid S. cerevisiae strains of w303 background we have used include: (a) no tag control (AM1176), (b) SCC1-6HA (AM1145), (c) BRN1-6HA (AM5708), (d) SCC2-6HIS3FLAG (AM6006), and (e) SCC1-6HA pMET3-CDC20 (AM1105) as previously described [9-12].

2. For studies of protein occupancy during meiosis we have used diploid $S$. cerevisiae strains of $S K \mathrm{Kl}$ background including (a) REC8-3HA ndt80D (AM4015), as previously described [13] and (b) REC8-6HIS-3FLAG (AM11000).

3. Haploid $S$. pombe strains used for calibration are: (a) RAD21$3 H A$ (spAM76), (b) RAD21-6HA (spAM635), (c) RAD216HIS-3FLAG (spAM1863), or (d) CND2-6HA (spAM1862).

4. YPDA media: $1 \%$ yeast extract, $2 \%$ peptone, $2 \%$ glucose. 


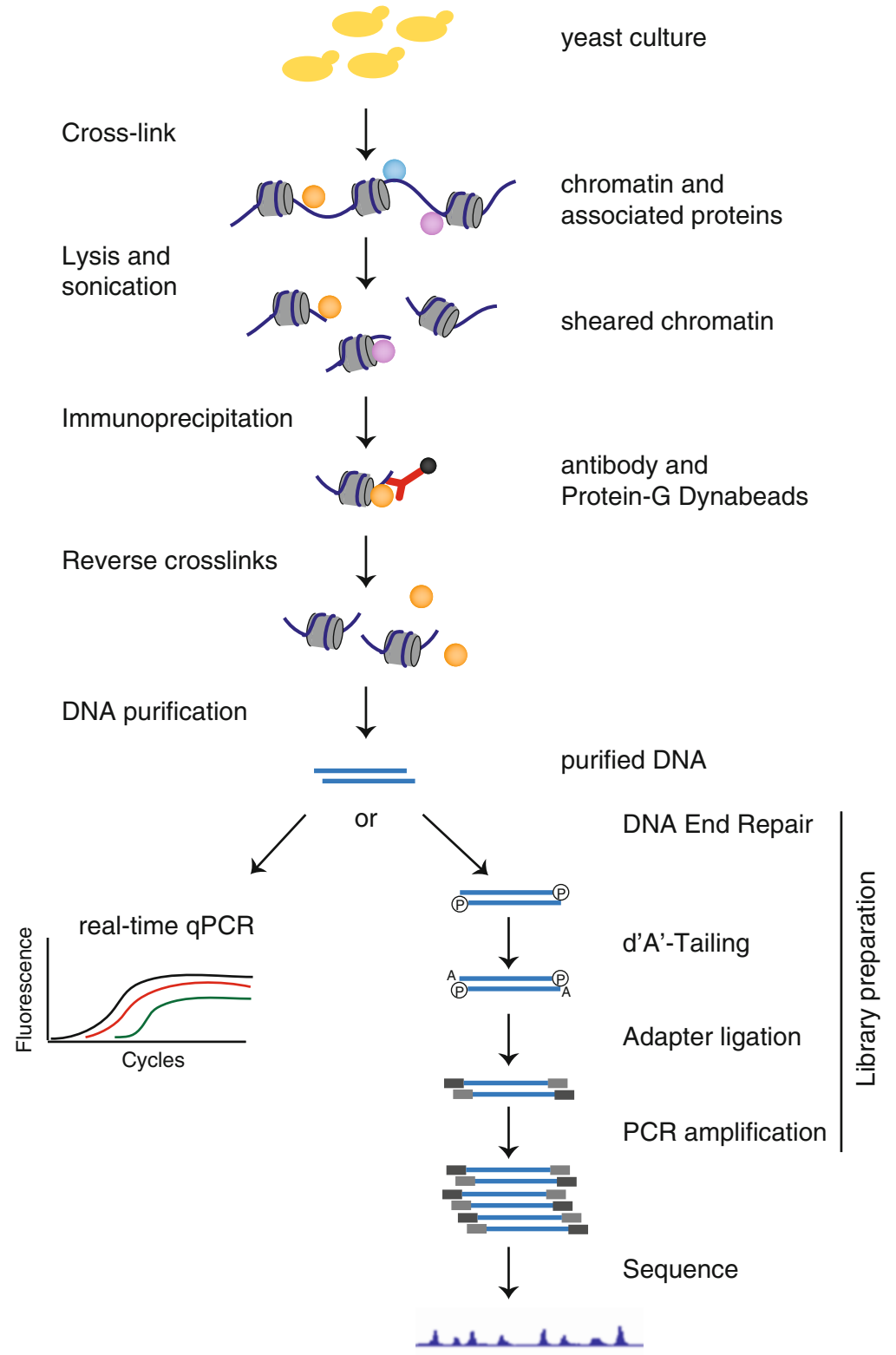

Fig. 1 Schematic overview of the workflow. Yeast cells are cross-linked to stabilize DNA-protein interactions. Cells are subsequently lysed, and chromatin then sheared. Proteins of interest are immunoprecipitated using protein-specific antibodies immobilized on Protein G Dynabeads. Samples are either analyzed by quantitative real-time PCR or DNA is further processed for ChIP-seq library preparation and subsequent deep sequencing 


\subsection{Equipment and Reagents}

5. YPG agar plates: $1 \%$ yeast extract, $2 \%$ peptone, $2.5 \%$ glycerol, $2 \%$ agar.

6. YPDA $4 \%$ agar plates: $1 \%$ yeast extract, $2 \%$ peptone, $4 \%$ glucose, $2 \%$ agar.

7. BYTA media: $1 \%$ yeast extract, $2 \%$ Bacto tryptone, $1 \%$ potassium acetate, $50 \mathrm{mM}$ potassium phthalate.

8. SPO media: $0.3 \%$ potassium acetate, $\mathrm{pH}$ 7.0.

9. YES media: $0.5 \%$ yeast extract, $3 \%$ glucose, $225 \mathrm{mg} / \mathrm{L}$ supplements.

1. $37 \%$ formaldehyde solution for molecular biology (see Note 1)

2. $2.5 \mathrm{M}$ glycine: Dissolve $93.8 \mathrm{~g}$ glycine in $\mathrm{ddH}_{2} \mathrm{O}$ (may require gentle heating) and bring up to $500 \mathrm{ml}$ with $\mathrm{ddH}_{2} \mathrm{O}$.

3. Diluent buffer: $0.143 \mathrm{M} \mathrm{NaCl}, 1.43 \mathrm{mM}$ EDTA, $71.43 \mathrm{mM}$ Hepes-KOH pH 7.5.

4. TBS buffer: $20 \mathrm{mM}$ Tris- $\mathrm{HCl} \mathrm{pH} 7.5,150 \mathrm{mM} \mathrm{NaCl}$.

5. $2 \times$ FA lysis buffer: $100 \mathrm{mM}$ Hepes-KOH pH 7.5, $300 \mathrm{mM}$ $\mathrm{NaCl}, 2$ mM EDTA, 2\% Triton X-100, 0.2\% Na-deoxycholate.

6. FastPrep screw-cap tubes.

7. $100 \mathrm{mM}$ PMSF (see Note 1)

8. Protease inhibitor tablets Complete EDTA free.

9. Zirconia/Silica beads $0.5 \mathrm{~mm}$ diameter.

10. FastPrep-24 5G Homogenizer.

11. Bioruptor Twin.

12. Dynabeads Protein G.

13. Magnetic rack.

14. ChIP Wash buffer 1 -low salt: $1 \times$ FA lysis buffer, $0.1 \%$ SDS, $275 \mathrm{mM} \mathrm{NaCl}$.

15. ChIP Wash buffer 2-high salt: $1 \times$ FA lysis buffer, $0.1 \%$ SDS, $500 \mathrm{mM} \mathrm{NaCl}$.

16. ChIP Wash buffer 3: $10 \mathrm{mM}$ Tris- $\mathrm{HCl}$ pH 8.0, 0.25 M LiCl, $1 \mathrm{mM}$ EDTA, 0.5\% NP-40. 0.5\% Na-deoxycholate.

17. ChIP Wash buffer 4 (TE): $10 \mathrm{mM}$ Tris- $\mathrm{HCl} \mathrm{pH}$ 8.0, 1 mM EDTA.

18. Chelex 100 Resin.

19. $10 \mathrm{mg} / \mathrm{ml}$ Proteinase $\mathrm{K}$

20. TES buffer: $50 \mathrm{mM}$ Tris- $\mathrm{HCl} \mathrm{pH} 7.5,10 \mathrm{mM}$ EDTA, 1\% SDS.

21. Nuclease-free molecular biology grade water.

22. Filter tips.

23. Luna Universal Probe qPCR Master Mix.

24. LightCycler 480 Multiwell Plate 96. 
25. LightCycler real-time PCR.

26. Qiagen purification kit.

27. LoBind DNA microcentrifuge tubes.

28. Quick blunting kit.

29. AMPure XP beads.

30. Klenow $3^{\prime}$ to $5^{\prime}$ exo minus.

31. Quick ligation kit (T4 DNA ligase).

32. NEXTflex DNA Barcodes-12 (Bioo Scientific; \#NOVA514102).

33. Phusion High-Fidelity DNA polymerase.

34. DynaMag-PCR magnet.

35. WizardSV Gel and PCR cleanup system.

36. Qubit dsDNA-HS Assay kit (Invitrogen).

37. Qubit Fluorometric Quantitation machine.

38. Agilent 2100 Bioanalyzer system.

39. High Sensitivity DNA Reagents kit (Agilent Technologies).

40. High Sensitivity DNA Chips (Agilent Technologies).

41. MiniSeq High throughput Reagent Kit (150-cycle) (Illumina).

42. Illumina Mini-seq.

3 Methods

Chromatin immunoprecipitation (ChIP) is broadly used to study chromatin dynamics. Changes in occupancy of chromosomal proteins at specific loci within the genome can be measured by using ChIP-qPCR. However, this technique is costly and time consuming with high variability per experiment. Alternatively, ChIP-seq can be used to measure differences in a protein's occupancy genome wide. Finally, calibrated ChIP-seq is essential when measuring changes in occupancy between different experimental samples.

Here we describe an optimized ChIP protocol for yeast SMC proteins that can be completed within 3 days for samples analyzed by qPCR and 4 days for samples to be further processed by calibrated deep sequencing. The protocol encompasses five distinct steps: cross-linking and cell harvesting; cell lysis and sonication; immunoprecipitation, decross-linking and DNA extraction and finally determination of the size and DNA concentration of sonicated samples. These five steps are outlined below.

3.1 Growth Conditions for SMC Proteins
S. cerevisiae strains for mitotic studies are grown in YPDA at $25^{\circ} \mathrm{C}$. The most consistent results, at least for cohesin, are obtained when cells are arrested in metaphase of mitosis prior to the ChIP 


\subsection{Cross-Linking and Cell Harvesting}

procedure. This can be achieved either by depletion of the anaphase-promoting complex subunit, Cdc20, or treatment of the cells with the microtubule-depolymerizing drug nocodazole. For depletion of Cdc20, we use a construct where CDC20 is under control of the methionine-repressible promoter, pMET3 (pMET3$C D C 20)$. Briefly for $\mathrm{Cdc} 20$ depletion, dilute an overnight culture to $\mathrm{OD}_{600}=0.2$ in minimal media lacking methionine and grow for $\mathrm{l}-2 \mathrm{~h}$ at $25{ }^{\circ} \mathrm{C}$ to $\mathrm{OD}_{600}=0.3-0.4$. Dilute culture back to $\mathrm{OD}_{600}=0.2$ in same media and arrest cells in Gl by adding $\alpha$-factor at $5 \mu \mathrm{g} / \mathrm{ml}$ for $1.5 \mathrm{~h}$ and at $2.5 \mu \mathrm{g} / \mathrm{ml}$ for an additional $1.5 \mathrm{~h}$. Check microscopically that at least $90 \%$ of cells are arrested before collecting on a filter (Whatman ME25, $0.45 \mu \mathrm{m}$ ), washing with 10 volumes of medium lacking sugar with the aid of a vacuum pump. Quickly resuspend cells in YPDA containing $8 \mathrm{mM}$ methionine and readd methionine to $4 \mathrm{mM}$ every $45 \mathrm{~min}$. Harvest cells after $2-2.5 \mathrm{~h}$ in a metaphase arrest confirmed by microscopy. For nocodazole arrest, dilute an overnight culture to $\mathrm{OD}_{600}=0.2$ in YPDA and grow for $1-2 \mathrm{~h}$ at $25^{\circ} \mathrm{C}$ to $\mathrm{OD}_{600}=0.3-0.4$. Dilute culture back to $\mathrm{OD}_{600}=0.2$ in YPDA media containing a mixture of nocodazole $(15 \mu \mathrm{g} / \mathrm{ml})$ and benomyl $(30 \mu \mathrm{g} / \mathrm{ml})$. Readd nocodazole every hour at $7.5 \mu \mathrm{g} / \mathrm{ml}$. Harvest cells after $2-2.5 \mathrm{~h}$ confirming metaphase arrest by microscopy.

For studies of protein occupancy during meiosis we have used diploid S. cerevisiae strains of SKI background including (a) REC83HA ndt80د (AM4015), as previously described [13] and (b) REC8-6HIS-3FLAG (AMI1000). For inducing meiosis, SKI strains are recovered from $-80{ }^{\circ} \mathrm{C}$ on YPG agar plates overnight at $30{ }^{\circ} \mathrm{C}$, before transferring to YPDA4\% agar plates for a further $12-30 \mathrm{~h}$ at $30{ }^{\circ} \mathrm{C}$. Cultures are inoculated in liquid YPDA at $30{ }^{\circ} \mathrm{C}$ with shaking for $\sim 24 \mathrm{~h}$, prior to inoculating into BYTA medium to $\mathrm{OD}_{600}=0.3$ overnight. The next morning, cells are spun down, washed with $\mathrm{dH}_{2} \mathrm{O}$ and resuspended in SPO medium to $\mathrm{OD}_{600}=1.8$ and shaken at $30{ }^{\circ} \mathrm{C}$. For prophase I arrest

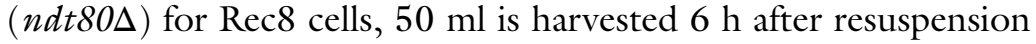
in sporulation medium and the arrest is confirmed by FACS.

S. pombe strains used for calibration are listed in Subheading 2.1 and are grown in YES at $30^{\circ} \mathrm{C}$.

1. For ChIP-qPCR to measure the localization of the cohesin subunit, Sccl, in cycling cells, harvest $50 \mathrm{ml}$ yeast cells of density $0.3-0.6 \mathrm{OD}_{600}$ grown in YPDA media. Alternatively, cells can be arrested in mitosis either by treatment with nocodazole or by depletion of Cdc20, as described above. For the less abundant cohesin loader subunit Scc2 and condensin subunit Brnl harvest $100 \mathrm{ml}$ yeast cells of density $0.3-0.6 \mathrm{OD}_{600}$ grown in YPDA. For the meiotic counterpart of cohesin, Rec8, harvest $50 \mathrm{ml}$ yeast cells of density $1.8 \mathrm{OD}_{600}$ grown in SPO media. To cross-link cells, add $5 \mathrm{ml}$ (11\% formaldehyde in 
diluent buffer) to give a final concentration of $1 \%$ formaldehyde in the culture. Gently rotate on an orbital shaker at $90 \mathrm{rpm}$ (with $1.8 \mathrm{~cm}$ orbit) at room temperature for $30 \mathrm{~min}$ for $\mathrm{Sccl}$, $\operatorname{Rec} 8, \mathrm{Scc} 2$, and Brnl (see Note 2).

2. For ChIP-seq for the aforementioned proteins grow $2 \times$ the amount of cell culture of yeast cells of density $0.3-0.6 \mathrm{OD}_{600}$ in YPDA media or $1.8 \mathrm{OD}_{600}$ in SPO media and process each $50 \mathrm{ml}$ sample individually. Cross-link as in step 1. For calibrated ChIP-seq see Note 3.

3. To quench cross-linking, add glycine at a final concentration of $125 \mathrm{mM}$ and incubate with gentle shaking for $5 \mathrm{~min}$ at room temperature (see Note 4).

4. Collect cells by centrifugation at $1800 \times g$ at $4{ }^{\circ} \mathrm{C}$.

5. Wash cells twice in $10 \mathrm{ml}$ ice-cold TBS buffer and once in $10 \mathrm{ml}$ ice-cold $1 \times$ FA lysis buffer supplemented with $0.1 \%$ SDS.

6. Collect cells by centrifugation at $1800 \times g$ at $4{ }^{\circ} \mathrm{C}$.

7. Carefully aspirate the supernatant and snap freeze pellets in liquid nitrogen in fastprep screw-cap tubes. Store the pellets at $-80{ }^{\circ} \mathrm{C}$ until ready to use (PAUSE POINT).

\subsection{Cell Lysis and Sonication}

1. Thaw cells on ice. Add 1 volume $(0.3-0.5 \mathrm{ml})$ of ice-cold $1 \times$ FA lysis buffer supplemented with $0.5 \%$ SDS, $1 \mathrm{mM}$ PMSF and protease inhibitors (Roche Complete EDTA-free tablet). For calibrated ChIP-seq see Note 3.

2. Add an equal volume $(200-250 \mu \mathrm{l})$ of $0.5-\mathrm{mm}$ Zirconium Silicate beads and lyse cells in a FastPrep-24 Homogenizer at $4{ }^{\circ} \mathrm{C}$ for $30 \mathrm{~s}$ (homogenization speed 6.5). Leave on ice for $10 \mathrm{~min}$ then repeat homogenization twice.

3. Place samples on ice. Dry the outside of the tubes, invert and puncture the tube bottom with a red flamed (under a Bunsen burner) $25 \mathrm{G} \times 5 / 8^{\prime \prime}$ needle, then immediately place the fastprep tube within a chilled $15 \mathrm{ml}$ conical Falcon tube already containing an empty fastprep tube and centrifuge at $1250 \times \mathfrak{g}$ for $3 \min$ at $4{ }^{\circ} \mathrm{C}$.

4. Transfer the entire lysate (both pellet and supernatant) to a prechilled $1.5 \mathrm{ml}$ Eppendorf tube. Centrifuge at $4{ }^{\circ} \mathrm{C}$ for 15 min at $16,000 \times g$.

5. Remove the supernatant by vacuum aspiration and resuspend the pellets thoroughly in $1 \mathrm{ml}$ of ice-cold $\mathrm{l} \times \mathrm{FA}$ buffer supplemented with $0.1 \%$ SDS, $1 \mathrm{mM}$ PMSF and protease inhibitors. Centrifuge at $4{ }^{\circ} \mathrm{C}$ for $15 \mathrm{~min}$ at $16,000 \times \mathrm{g}$. Discard supernatant (notice the presence of a pellet with a glass-like layer. This is the cross-linked chromatin). 
3.4 Immunoprecipitation, Decrosslinking, and DNA Extraction
6. Resuspend washed chromatin pellets well in $0.3 \mathrm{ml}$ ice-cold $1 \times$ FA buffer containing $0.1 \%$ SDS, $1 \mathrm{mM}$ PMSF and protease inhibitors.

7. Shear the chromatin by sonication, using a Bioruptor Twin with circulating water bath at a temperature of less than $5{ }^{\circ} \mathrm{C}$ and power settings: High, $30 \mathrm{~s} \mathrm{ON} / 30 \mathrm{~s}$ OFF, 30 cycles (see Note 5 ).

8. Centrifuge the sonicated mixture at $16,000 \times g$ for $15 \mathrm{~min}$ at $4{ }^{\circ} \mathrm{C}$ to remove cell debris and transfer the supernatant into a new cold Eppendorf tube containing $1 \mathrm{ml} \mathrm{l} \times \mathrm{FA}$ lysis buffer with $0.1 \%$ SDS, $1 \mathrm{mM}$ PMSF, protease inhibitors. Mix by inversion and centrifuge at $16,000 \times g$ for $15 \mathrm{~min}$ at $4{ }^{\circ} \mathrm{C}$.

9. Carefully transfer the supernatant into a new, cold Eppendorf tube. This chromatin preparation will be used for the immunoprecipitation in Subheading 3.4 ( see Note 6).

10. Store $10 \mu \mathrm{l}$ of supernatant at $-20{ }^{\circ} \mathrm{C}$. This will be the "Input" sample.

11. Use $100 \mu \mathrm{l}$ of the chromatin preparation (step 9) to determine fragment size (see Subheading 3.5).

1. Prewash $(n \times 15) \mu$ l of Protein G Dynabeads $(n=$ number of IP samples) in $1 \mathrm{ml}$ ice-cold $1 \times$ FA buffer containing $0.1 \%$ SDS, $1 \mathrm{mM}$ PMSF and protease inhibitors with rotation for $5 \mathrm{~min}$. Place the microcentrifuge tubes on a magnet and discard the supernatant. Repeat three times.

2. Add the antibody against the protein of interest to $1 \mathrm{ml}$ of chromatin extract (see Subheading 3.3, step 9) and $15 \mu \mathrm{l}$ of prewashed Dynabeads and mix. Incubate on a rotating wheel at $4{ }^{\circ} \mathrm{C}$ overnight (see Notes 6 and 7 ).

3. Place the tubes on the magnet and discard the supernatant. Perform the following washes, using $1 \mathrm{ml}$ per sample of Wash buffer on a rotating wheel for $5 \mathrm{~min}$ at room temperature. Discard supernatants after each wash.
(a) ChIP Wash Buffer 1-low salt.
(b) ChIP Wash Buffer 2-high salt.
(c) ChIP Wash Buffer 3.
(d) ChIP wash Buffer 4.

4. Following the final wash, place the samples on magnetic rack and discard the supernatant without disturbing the beads.

5. (a) To reverse cross-linking and isolate DNA for qPCR, use Chelex 100 as previously described [14]. Add $0.2 \mathrm{ml} \mathrm{10 \%}$ slurry (wt/vol) in sterile water Chelex-100 resin directly to the washed Dynabeads (IP sample) and to $10 \mu$ of thawed "Input" samples (see Subheading 3.3, step 10). Keep the 
Chelex beads in suspension while pipetting. Briefly vortex samples to mix the slurry and boil for $10 \mathrm{~min}$. Cool the tubes to room temperature and quickly centrifuge condensate to the bottom of the tube at $400 \times g$. Proceed immediately to step 6 ( see Note 8)

(b) For ChIP-seq preparation after the final wash (see Subheading 3.4, step 4), remove tubes from magnetic rack and perform the following steps:

(1) Pool magnetic beads of the same IP samples together and resuspend in $0.2 \mathrm{ml}$ of TES buffer. (2) Elute the immunoprecipitated chromatin by incubating the resuspended beads in TES buffer at $65{ }^{\circ} \mathrm{C}$ for $15 \mathrm{~min}$. (3) Place tubes on magnetic rack and transfer the supernatant, termed the IP sample, to a new LoBind DNA tube. (4) Add $190 \mu$ of TES to $10 \mu$ pooled Input samples in a LoBind DNA tube. (5) Decross-link both IP and Input samples at $65^{\circ} \mathrm{C}$ overnight (minimum $6 \mathrm{~h}$ ). (6) Cool the samples and add $2 \mu \mathrm{l}$ of RNAse $(10 \mathrm{mg} / \mathrm{ml})$ for $1 \mathrm{~h}$ at $37^{\circ} \mathrm{C}$ to degrade RNA. (7) Add $20 \mu \mathrm{l}$ of $10 \mathrm{mg} / \mathrm{ml}$ Proteinase K per $0.2 \mathrm{ml}$ of solution to both IP and Input samples and incubate at $65{ }^{\circ} \mathrm{C}$ for 2 h. (8) Purify ChIP-seq library by using Wizard SV purification kit according to manufacturer's instructions. Proceed to step 9.

6. Add $2.5 \mu \mathrm{l}$ Proteinase $\mathrm{K}(10 \mathrm{mg} / \mathrm{ml})$ to each sample and incubate on a heat block at $55{ }^{\circ} \mathrm{C}$ for $30 \mathrm{~min}$ with occasional mixing to resuspend beads.

7. Boil the samples at $100{ }^{\circ} \mathrm{C}$ for $10 \mathrm{~min}$ to inactivate the Proteinase K. Spin the tubes briefly at $400 \times g$ and carefully transfer approximately $120 \mu \mathrm{l}$ of the DNA supernatant, termed the IP sample in a new tube. Make sure not to transfer any Chelex resin as it can lead to loss of PCR signal. Store samples at $-20^{\circ} \mathrm{C}$. (PAUSE POINT).

8. Purified DNA from step 7 can be used in qPCR. We use Luna Universal Probe qPCR Master Mix in a $10 \mu \mathrm{l}$ reaction $(3 \mu \mathrm{l}$ DNA template (for Input use 1:300 for IP use 1:6 dilutions), $0.125 \mu \mathrm{l}$ primer pair $(20 \mu \mathrm{M}$ each $), 5 \mu \mathrm{l}$ master mix and $\mathrm{ddH}_{2} \mathrm{O}$ ) in a 96-well plate and run the following program: initial denaturation: $95^{\circ} \mathrm{C}$ for $1 \mathrm{~min}$; denaturation: $95^{\circ} \mathrm{C}$ for $15 \mathrm{~s}$; extension: $60{ }^{\circ} \mathrm{C}$ for $30 \mathrm{~s}, 42$ cycles, melting curve according to Lightcycler 480 recommendations. To determine the ChIP enrichment (i.e., ChIP/Input value), $\Delta C_{\mathrm{t}}$ is calculated using the following formula: $\Delta C_{\mathrm{t}}=C_{\mathrm{t}}^{\text {ChIP }}-\left(C_{\mathrm{t}}^{\text {Input }}-\log\right.$ primer efficiency (Input dilution factor)). From this, the ChIP enrichment is calculated using: ChIP/Input $=$ (primer efficiency) ${ }^{(-\Delta C t)}$, where $C_{t}$ values are mean threshold cycles of PCR performed in triplicate per DNA sample. Data analysis is performed using Microsoft Excel software (see Note 9). 


\subsection{Determine the Size of Sonicated Samples and the DNA Concentration}

3.6 ChIP-seq Library preparation
9. To determine whether the amount of immunoprecipitated DNA is sufficient for library preparation for ChIP-seq, quantify $3 \mu \mathrm{l}$ of the ChIP products and Input using the Qubit HS kit. Most commonly, immunoprecipitated DNA yields are in the range of 2-10 ng.

The sonicated chromatin samples (see Subheading 3.3, step 11) can be used to determine the fragment size.

1. To a $100 \mu \mathrm{l}$ of Input sample add $80 \mu \mathrm{l}$ of TE buffer containing $300 \mathrm{mM} \mathrm{NaCl}$ and decross-link at $65{ }^{\circ} \mathrm{C}$ overnight.

2. Add $2 \mu \mathrm{l}$ of RNase $\mathrm{A}(10 \mathrm{mg} / \mathrm{ml})$ and incubate at $37^{\circ} \mathrm{C}$ for $1 \mathrm{~h}$ ( see Note 10).

3. Add $20 \mu \mathrm{l}$ of Proteinase $\mathrm{K}(10 \mathrm{mg} / \mathrm{ml})$ and incubate at $65{ }^{\circ} \mathrm{C}$ for $2 \mathrm{~h}$.

4. Purify DNA using a PCR purification kit (see Subheading 2.2). Run purified DNA on a $2 \%$ agarose gel with a 100 bp DNA ladder marker to determine fragment size. Ideally sonication should yield an enrichment of fragments between 200 and 400 bp (Fig. 2a).

5. DNA concentration can be measured by Qubit HS assay kit.

There are commercially available kits for generating DNA libraries but it is relatively straightforward and cost effective to create libraries using standard molecular biology reagents and custom oligonucleotides. This protocol can be completed within 1 day, and it comprises five distinct steps: blunting reaction; dA-Tailing to the $3^{\prime}$ end of the DNA fragments; adapter ligation to the DNA fragments; PCR for enrichment of adapter modified DNA fragments; and library size selection. Finally, given the high cost of ChIP-seq runs and the time-intensive bioinformatics analysis and data validation, it is essential that the quality and the concentration of the libraries is validated by an Agilent Bioanalyzer (see Subheading 3.6.5, step 7) prior to sequencing. These five steps are outlined below.

1. Perform the blunting reaction using the following recipe: if making multiple libraries prepare a master mix of buffer, dNTPs, and enzyme, and then aliquot to the required ChIP purified DNA. The final volume should be $50 \mu \mathrm{l}$ (see Note 11$)$.

(a) 1-20 ng (ideally $2 \mathrm{ng}$ ) ChIP DNA

(b) $5 \mu \mathrm{l} 10 \times$ blunting buffer

(c) $5 \mu \mathrm{ll} \mathrm{mM} \mathrm{dNTPs}$

(d) $1 \mu$ l blunting enzyme.

2. Incubate at room temperature $\left(25^{\circ} \mathrm{C}\right)$ for $45 \mathrm{~min}$. 
A

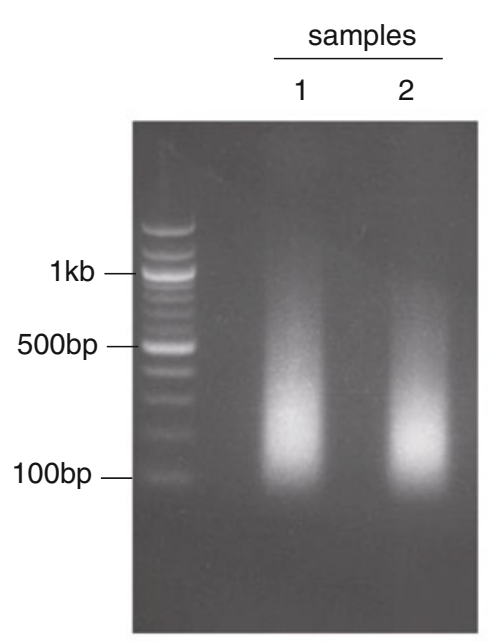

B

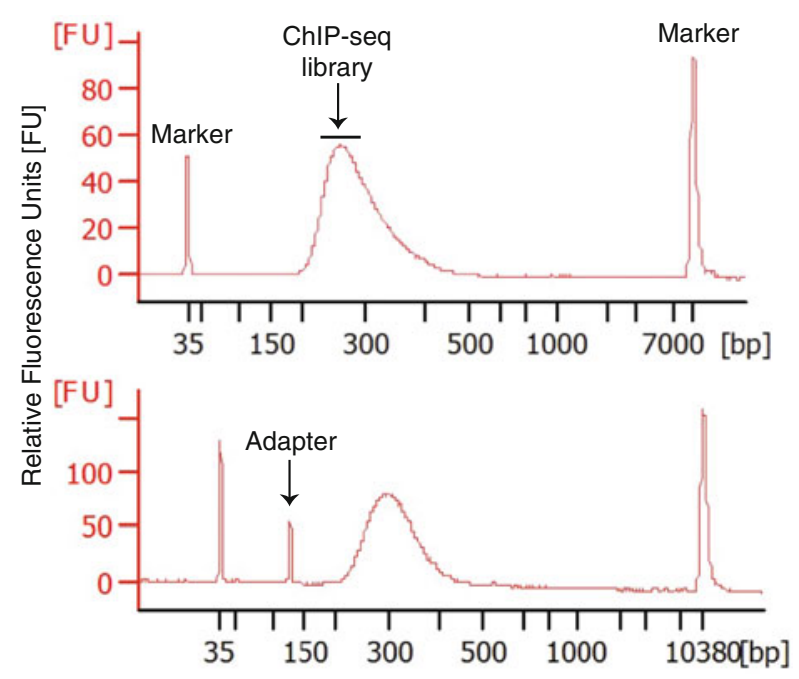

C Scc1-6HA enrichment on Chromosome V

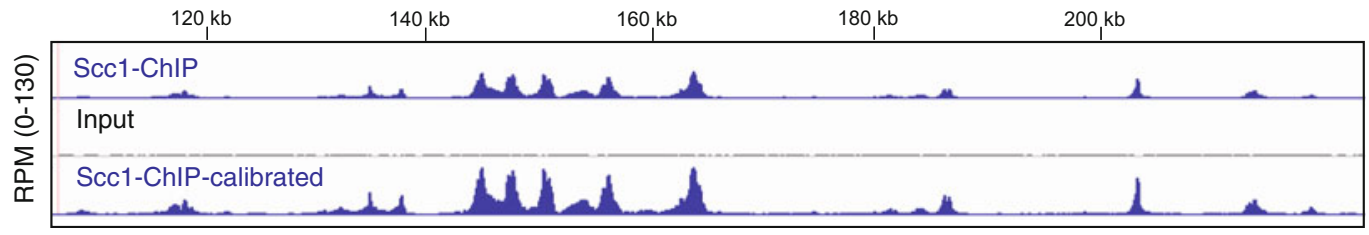

Fig. 2 (a) Representative image of mitotic yeast cells sonicated with a Bioruptor Twin (Diagenode) for a 30-min round (power setting: High, $30 \mathrm{~s}$ 0N/30 s OFF). DNA from two different samples was loaded on a $\%$ agarose gel with a 100 bp marker ladder. (b) Representative optimal BioAnalyzer trace (upper panel) and contaminated trace with adapter (bottom panel) (c). Examples of profiles generated by chromatin immunoprecipitation followed by sequencing (ChIP-seq) of the cohesin subunit Scc1 in wild-type cells (IP shown in blue; Input shown in grey) and calibrated with $S$. pombe Scc1 distribution in representative chromosome V (IP shown in blue, bottom panel)

3.6.2 "A"-Tailing Reaction
3. Perform a 1.6:1 AMPure XP selection by adding $80 \mu \mathrm{l}$ AMPure beads to the $50 \mu$ l blunting reaction (see Subheading 3.7).

4. Elute in $30 \mu \mathrm{l}$ in $\mathrm{ddH}_{2} \mathrm{O}$ and take $27.7 \mu \mathrm{l}$ to a new DNA LoBind Eppendorf.

1. Use end-repaired DNA (from Subheading 3.6.1, step 4) to perform "A"-tailing reaction using the following recipe: if making multiple libraries prepare a master mix of buffer, dATP, and enzyme, and then aliquot to the required end-repaired DNA. The final volume should be $30 \mu \mathrm{l}$.

(a) $27.7 \mu$ end-repaired DNA

(b) $3.3 \mu \mathrm{l} 10 \times \mathrm{NEB}$ buffer 2 
3.6.3 Adapter Ligation Reaction

3.6.4 PCR Amplification Reaction (c) $1 \mu 10 \mathrm{mM}$ dATP

(d) $1 \mu$ l Klenow $3^{\prime}$ to $5^{\prime}$ exo minus $(5 \mathrm{U} / \mu \mathrm{l})$.

2. Incubate at $37^{\circ} \mathrm{C}$ for $30 \mathrm{~min}$.

3. Heat-inactivate Klenow enzyme at $75{ }^{\circ} \mathrm{C}$ for $5 \mathrm{~min}$.

4. Place reaction on ice for $5 \mathrm{~min}$.

5. Proceed immediately to adapter ligation reaction (see Subheading 3.6.3).

1. Use dA-tailed DNA (from Subheading 3.6.2, step 5) to perform the adapter ligation reaction using the following recipe: the final volume should be $70 \mu \mathrm{l}$. Use different barcoded adapters for each Input and IP sample (see Note 12).

(a) $33 \mu \mathrm{l}$ "A"-tailed DNA

(b) $35 \mu \mathrm{l} 2 \times$ Quick Ligase buffer

(c) $1 \mu \mathrm{l} 0.5 \mu \mathrm{M}$ Adapters [15]

(d) $1 \mu \mathrm{l}$ Quick T4 DNA ligase $(2000 \mathrm{U} / \mu \mathrm{l})$.

2. Incubate at room temperature for $25 \mathrm{~min}$.

3. Perform a 1:1 AMPure selection by adding $70 \mu \mathrm{l}$ AMPure XP beads to the $70 \mu$ ladapter ligation reaction (see Subheading 3.7).

4. Elute in $52 \mu \mathrm{l}$ in $\mathrm{ddH}_{2} \mathrm{O}$. Transfer $50 \mu \mathrm{l}$ to a new DNA LoBind Eppendorf.

5. DNA fragments over $100 \mathrm{bp}$ will bind to beads and be eluted.

6. Perform another 1:1 AMPure selection by adding $50 \mu \mathrm{l}$ AMPure beads to the $50 \mu \mathrm{l}$ elution fraction from step 4 .

7. Elute in $33 \mu \mathrm{lddH_{2 }} \mathrm{O}$ and take up $30 \mu \mathrm{l}$ to a new DNA LoBind Eppendorf.

8. DNA fragments above $100 / 200$ bp will bind to beads and be eluted.

1. Transfer $10 \mu \mathrm{l}$ per sample of the supernatant (see Subheading 3.6.3, step 7) to a $0.2 \mathrm{ml} \mathrm{PCR} \mathrm{tube} \mathrm{and} \mathrm{set} \mathrm{up} \mathrm{the} \mathrm{following}$ PCR reaction on ice in a final volume of $50 \mu$.

(a) $10 \mu \mathrm{l}$ adapter-ligated DNA

(b) $10 \mu \mathrm{l} 5 \times$ Phusion HF buffer

(c) $4 \mu \mathrm{l} 2.5 \mathrm{mM} \mathrm{dNTPs}$

(d) $2 \mu \mathrm{l} 12.5 \mu \mathrm{M}$ Primer mix

(e) $1.5 \mu \mathrm{LMSO}$

(f) $0.5 \mu \mathrm{l}$ Phusion polymerase

(g) $22 \mu \mathrm{lddH} 2 \mathrm{O}$. 
3.6.5 Double-Sided AMPure Selection and Library Elution

\subsection{AMPure Purification Protocol}

2. Amplify DNA with the following PCR program: $98^{\circ} \mathrm{C}$ for $30 \mathrm{~s}$, $12-18$ cycles of $\left(98^{\circ} \mathrm{C}\right.$ for $10 \mathrm{~s}, 65^{\circ} \mathrm{C}$ for $30 \mathrm{~s}, 72^{\circ} \mathrm{C}$ for $\left.30 \mathrm{~s}\right)$, and $72^{\circ} \mathrm{C}$ for $5 \mathrm{~min}$ (see Note 13 ).

1. Perform a $0.65 \times: 1$ AMPure selection. Add to the $50 \mu \mathrm{l} \mathrm{PCR}$ reaction (see Subheading 3.6.4, step 2) $31.85 \mu$ AMPure XP beads, resuspend by pipetting and leave at room temperature for $10 \mathrm{~min}$ to bind. Place $0.2 \mu \mathrm{l}$ PCR tubes in a DynaMag-PCR magnet for $5 \mathrm{~min}$.

2. KEEP THE SUPERNATANT, this will contain fragments $<300$ bp. To $80 \mu$ l supernatant add $50 \mu$ l Ampure beads (adjust bead volume for smaller supernatant volumes) and perform AMPure selection according to Subheading 3.7. DNA fragments of 100-250 bp will bind to the beads.

3. Elute in $52 \mu \mathrm{EB}$ (Qiagen purification kit) or ultrapure $\mathrm{ddH}_{2} \mathrm{O}$ and pipet $50 \mu$ to a new DNA LoBind Eppendorf.

4. Perform another 1:1 AMPure selection by adding $50 \mu \mathrm{l}$ AMPure beads to the $50 \mu \mathrm{l}$ elution fraction from step 3 . DNA fragments above $100 / 200 \mathrm{bp}$ will bind to the beads.

5. Elute in $33 \mu \mathrm{LB}$ buffer (Qiagen purification kit) and transfer $30 \mu \mathrm{l}$ to a new LoBind Eppendorf.

6. Determine DNA library concentration by Qubit HS kit (use $2 \mu \mathrm{l})$.

7. Run the library on a Bioanalyzer to determine average fragment size and general purity. Use a High Sensitivity DNA Kit (Agilent Technologies) as per manufacturer's instructions. Fragments of the sequencing library should have a size range of 150-300 bp (Fig. 2b, upper panel). If not pure, that is, adapter dimers are visible (Fig. 2b, lower panel), perform 1:1 AMPure purification to remove small adapter dimers.

8. Libraries are now ready for sequencing using a sequencing platform of choice.

9. The final concentration of the library to load on the flow cell is 1.5 pM with an Input-IP ratio 15\%:85\%. Perform paired-end sequencing with $76 \mathrm{bp}-76 \mathrm{bp}$ for Readl and Read 2 (see Note 14).

AMPure purification relies on the principle of solid-phase reversible immobilization (SPRI) as previously described [16]. SPRI beads are paramagnetic and coated with carboxyl molecules, which reversibly bind DNA in the presence of polyethylene glycol (PEG) and salt (20\% PEG, $2.5 \mathrm{M} \mathrm{NaCl}$ mix). PEG causes the negatively charged DNA to bind on the bead surface. This DNA immobilization is dependent on the concentration of PEG and salt in the reaction, and the volumetric ratio of SPRI beads to DNA is critical. 
Equal volume of beads to DNA will give an SPRI -DNA ratio of one. As this ratio is changed the length of fragments binding and/or left in solution also changes. A lower SPRI-DNA ratio results in larger fragments at elution.

1. Equilibrate an aliquot for all purifications needed of AMPure $\mathrm{XP}$ beads at room temperature for $30 \mathrm{~min}$ before use. Vortex to resuspend.

2. Pipet carefully the indicated amounts so that no extra beads adhere to the outside of the tip.

3. Add the AMPure XP beads to DNA in solution and immediately mix thoroughly by repeated pipetting.

4. Incubate at room temperature for $10 \mathrm{~min}$ to allow binding of DNA to beads.

5. Place on a magnetic rack for $5 \mathrm{~min}$.

6. Remove and discard the supernatant taking great care not to take any beads.

7. Keep sample on magnetic rack and add $250 \mu \mathrm{l}$ of freshly prepared $80 \%$ ethanol without disturbing the beads.

8. Incubate for $30 \mathrm{~s}$. Remove and discard all supernatant.

9. Repeat steps 7 and 8 once more.

10. Let the beads air-dry for $2-3 \mathrm{~min}$ at room temperature (see Note 15).

11. Add the recommended amount of elution buffer (EB from Qiagen kit or ultrapure $\left.\mathrm{ddH}_{2} \mathrm{O}\right)$ and resuspend the beads by pipetting.

12. Incubate at room temperature for $3 \mathrm{~min}$.

13. Place in magnetic rack for $2 \mathrm{~min}$.

14. Transfer the supernatant to a new DNA LoBind Eppendorf tube (if, for example, eluting in $30 \mu \mathrm{l}$, remove $28 \mu \mathrm{l}$ very slowly, being careful to prevent bead carryover. If beads are accidentally removed, pipet the sample back into the tube and allow the beads to bind).

3.8 Bioinformatics Analysis
We carry out all data processing on the Ubuntu 16.04 (xenial) operating system. Basecalls are performed using Illumina RealTime Analysis (RTA2) software on the MiniSeq System. FastQC is used to assess the quality of the raw sequence data (fastq reads), with fastq-screen used to detect any unwanted contamination. All quality control reports were aggregated with MultiQC [17]. ChIPseq paired end reads are trimmed with cutadapt, any adapter sequence is removed from the $3^{\prime}$ end of reads using standard 
Illumina adapter sequences. Quality trimming is also performed from the $3^{\prime}$ end using a user-defined cutoff (phred-33 quality 10 ). After adapter and quality trimming, any read less than the defined minimum length $(30 \mathrm{bp})$ is removed. Reads are mapped to both $S$. pombe calibration genome and S. cerevisiae w303 experimental genome, retaining only those reads that map to each reference.

To obtain reads mapping only to SacCer W303; trimmed fastq reads are first mapped with the MiniMap2 alignment tool [18] ("-ax sr" short genomic reads) to reference $S$. pombe, whereas unmapped $S$. pombe reads are selected using SAMtools [19] (include SAM Flag -F 4) and converted back into fastq format (interleaved), those unmapped $S$. pombe reads are then mapped to SacCer W303. Here, any unmapped reads are filtered out using samtools (exclude SAM Flag -F 4) and rDNA regions are removed from the section of chromosome XII which corresponds to the repetitive rDNA using BEDtools intersect [20], as this region is saturated with reads. To obtain reads mapping only to $S$. pombe the above process is performed in reverse. The original trimmed reads are also mapped to SacCer w303, unmapped SacCer w303 reads were selected using SAMtools, those unmapped SacCer w303 reads are then mapped to $S$. pombe, and unmapped reads are filtered out using SAMtools. Mitochondrial DNA is excluded using SAMtools for both genomes. In order to visualize mapped reads, bedGraphs are created from the aligned Binary Alignment Map (BAM) files using BEDtools genomeCoverageBed with reads per millions (RPM) normalization (calculated with custom script using SAMtools flagstat output) \& UCSC wigToBigWig is used to convert these into BigWigs. For meiotic samples, where SKI strains were used, mapping was performed to the SKl genome, rather than SacCer3 as described above.

To generate the calibrated ChIP bigWigs; SAMtools flagstat is used to count reads mapping to SacCer3 w303 and $S$. pombe only for each sample, these values are then used to calculate the Occupancy Ratio (OR) value as previously described [8]; Wc* IPx/ $\mathrm{Wx}{ }^{*} \mathrm{IPc}(\mathrm{W}=$ Input; IP $=\mathrm{chIP} ; \mathrm{c}=$ calibration genome (S. pombe); $\mathrm{x}=$ experimental genome ( value is used to calibrate ChIP bedgraphs using BEDtools genomeCoverageBed and convert to bigWig with UCSC wigToBigWig. These bigWigs are viewable in a genome browser such as Integrative Genomics Viewer (IGV) [21] or the ensembl genome browser. All bigWigs from our published analyses are submitted to the Genome Expression Omnibus (GEO) archive and raw reads to the Sequence Read Archive (SRA). 


\section{Notes}

1. Formaldehyde and PMSF are toxic if inhaled, ingested or absorbed through the skin. Always wear a lab coat and gloves, and work in a chemical hood.

2. The cross-linking time and formaldehyde concentration can affect both the efficiency of chromatin shearing and of antigen precipitation. Shorter cross-linking times (5-10 min), lower formaldehyde concentrations ( $1 \%, \mathrm{wt} / \mathrm{vol})$, or both, may improve shearing efficiency. However, for some proteins, especially those that do not directly bind DNA, this might reduce the efficiency of cross-linking and thus the yield of precipitated chromatin. It is advisable to perform a cross-linking time course to determine optimal fixation conditions.

In vivo cross-linking for ChIP is traditionally achieved with formaldehyde; however, formaldehyde is a short spacer arm cross-linker $(2 \AA)$, limiting its functionality. For higher order interactions, longer cross-linkers such as EGS (16.1 A) or DSG $(7.7 \AA)$ or combination of cross-linkers can be used so to more efficiently trap larger protein complexes with complex quaternary structure [22].

3. For calibrated ChIP-seq use a $2: 1$ ratio of $S$. cerevisiae to $S$. pombe cells, as measured by $\mathrm{OD}_{600}$, mix pellets of different organisms in a single fastprep tube and lyse together as previously described [8]. Use the same batch of $S$. pombe in all samples of the same experiment. Perform each IP individually and pool samples together after the final wash step by combining beads from multiple IPs in the same $200 \mu$ of TES elution buffer (see Subheading 3.4, step 4). Both calibration and experimental genomes need to express proteins tagged with the same epitope for immunoprecipitation and the calibration organism needs to be sufficiently similar that the ChIP protocol works for both.

4. Addition of glycine to quench the formaldehyde is particularly important when harvesting large volumes of cell culture as the harvesting process can be long and thereby can increase fixation time between samples.

5. Sonication conditions must be determined empirically for each cell type, and sonicator model; the optimal average DNA fragment size is below $0.5 \mathrm{~kb}$. Overfragmentation of chromatin is not recommended as it can damage the protein epitope targeted by the antibody of choice. If the Diagenode water bath sonicator is not available, a probe sonicator or Covaris instrument can also be used. Sonication time and intensity will need 
to be optimized and DNA fragment size determined as in Subheading 3.5.

6. The amount of SDS in immunoprecipitation can interfere with antibody binding efficiency therefore, lower amount of SDS can also be used. Either omit SDS in $2 \mathrm{xFA}$ buffer or reduce SDS added afterward to a final concentration of $0.05 \%$ before chromatin immunoprecipitation.

7. The amount of antibody added should be in excess of the protein being immunoprecipitated and should be determined empirically. We use the following amounts of antibodies per IP: $10 \mu \mathrm{l} \mathrm{9E10}$ (Tonbo Biosciences) $7.5 \mu \mathrm{l}$ 12CA5 (Roche), $10 \mu \mathrm{l}$ SV5-PKl (Bio-Rad), $10 \mu \mathrm{l}$ anti-GFP (Roche), and $5 \mu \mathrm{l} \mathrm{M} 2$ FLAG (Sigma). No blocking and preclearing is required for the magnetic beads.

8. Variation in the amount of beads added can affect the specific signal-background ratio. Make sure to keep the slurry suspended while distributing.

9. To increase accuracy and reproducibility, we advise the use of an electronic dispensing pipette for qPCR. For primer design we recommend the use of Prime3Plus software. In the general settings of the software, we use product size range 70-200 bp (optimal amplicon size $\sim 120 \mathrm{bp}$ ), optimal primer size $20 \mathrm{bp}$ in length and optimal primer Tm for use with Luna Universal Probe qPCR Master Mix should be designed to anneal at $60{ }^{\circ} \mathrm{C}$, with optimal primer $\mathrm{GC} \%$ between $50 \%$ and $60 \%$. Once primers are designed determine their efficiency and specificity using genomic DNA prior to performing qPCR with ChIP DNA sample. Finally, also include a No Template Control (NTC) in the reaction, where no amplification and no melting curve should be generated.

10. RNase treatment is important as high levels of RNA will interfere with DNA purification when using commercially available PCR purification kits. DNA yield can be markedly reduced as the columns become saturated.

11. For library preparation we recommend to use only filter-tips and $1.5 \mathrm{ml}$ DNA LoBind tubes.

12. Always keep adapters on ice. The quantity of adapters stated here is recommended for $2 \mathrm{ng}$ of DNA; however, the amount of adapters should be proportional to the amount of DNA used. Optimal concentration of adapters used is essential. High concentration can lead to adapter contamination in the final library, which can be visualized on the Bioanalyzer (Fig. 2b). We use for this protocol the NEXTflex DNA 
Barcodes-12 (Bioo Scientific; \#NOVA-514102). The NEXTflex DNA Barcodes utilize an indexed adapter containing a $6 \mathrm{nt}$ unique sequence. Details can be found in manufacturer's manual.

13. When PCR for library amplification is performed, minimal cycling is desirable. The fewer number of PCR cycles used to amplify libraries, the less biased the resulting libraries will be for the products that are more efficiently amplified. Overamplification can result in daisy-chains of fragments that can be visualized as a higher molecular weight peak on the Bioanalyzer. If the library amplification fails, more DNA template can be used. For IP samples use up to $20 \mu \mathrm{l}$ of template DNA.

14. Several different next generation sequencers are available; for this protocol we use the Illumina platform. While platforms vary by target sequence length, accuracy and cost all give reproducibly comparable results. In order to perform experiments in a cost-effective manner, multiplexing can be used, that is, multiple ChIP-seq libraries, each carrying a different barcode to identify different samples can be sequenced together on a single flow cell of MiniSeq or lane of a Hiseq. The output of the Illumina MiniSeq is $\sim 25 \mathrm{M}$ clusters. We typically, sequence 8-10 barcoded uncalibrated samples in a single pooled library or $4-5$ barcoded calibrated samples in a single pooled library. Typically one ChIP library generates six to ten million reads $[23,24]$. However, the above is subject on the level of enrichment of the protein of interest and the resolution required.

15. Overdrying the AMPure beads after the washing step will negatively impact on the DNA recovery. Beads are dry enough as soon as they lose their sheen.

\section{Acknowledgments}

We are grateful to Manu Shukla for discussions and comments on the ChIP-seq library preparation and for kindly providing a representative Bioanalyzer image, Nicholas Toda, Jesus Torres-Garcia, and Flora Paldi for sharing tips on the ChIP-seq library protocol and Stefan Galangher and Lesley Clayton for general comments on the manuscript. This work was funded by Wellcome through a Senior Research Fellowship to AM and a Wellcome Centre core grant [107827 and 203149]. 


\section{References}

1. Solomon MJ, Varshavsky A (1985) Formaldehyde-mediated DNA-protein crosslinking: a probe for in vivo chromatin structures. Proc Natl Acad Sci U S A 82 (19):6470-6474

2. Solomon MJ, Larsen PL, Varshavsky A (1988) Mapping protein-DNA interactions in vivo with formaldehyde: evidence that histone $\mathrm{H} 4$ is retained on a highly transcribed gene. Cell 53 (6):937-947

3. Gilmour DS, Lis JT (1984) Detecting proteinDNA interactions in vivo: distribution of RNA polymerase on specific bacterial genes. Proc Natl Acad Sci U S A 81(14):4275-4279

4. Kuo MH, Allis CD (1999) In vivo crosslinking and immunoprecipitation for studying dynamic protein:DNA associations in a chromatin environment. Methods 19(3):425-433. https://doi.org/10.1006/meth.1999.0879

5. Thorne AW, Myers FA, Hebbes TR (2004) Native chromatin immunoprecipitation. Methods Mol Biol 287:21-44. https://doi.org/10. 1385/1-59259-828-5:021

6. Bonhoure N, Bounova G, Bernasconi D, Praz V, Lammers F, Canella D, Willis IM, Herr W, Hernandez N, Delorenzi M, Cycli XC (2014) Quantifying ChIP-seq data: a spiking method providing an internal reference for sample-to-sample normalization. Genome Res 24(7):1157-1168. https://doi.org/10.1101/ gr.168260.113

7. Orlando DA, Chen MW, Brown VE, Solanki S, Choi YJ, Olson ER, Fritz CC, Bradner JE, Guenther MG (2014) Quantitative ChIP-Seq normalization reveals global modulation of the epigenome. Cell Rep 9 (3):1163-1170. https://doi.org/10.1016/j. celrep.2014.10.018

8. Hu B, Petela N, Kurze A, Chan KL, Chapard C, Nasmyth K (2015) Biological chromodynamics: a general method for measuring protein occupancy across the genome by calibrating ChIP-seq. Nucleic Acids Res 43 (20):e132. https://doi.org/10.1093/nar/ gkv670

9. Fernius J, Marston AL (2009) Establishment of cohesion at the pericentromere by the Ctfl9 kinetochore subcomplex and the replication fork-associated factor, Csm3. PLoS Genet 5 (9):e1000629. https://doi.org/10.1371/jour nal.pgen.1000629

10. Fernius J, Nerusheva OO, Galander S, Alves Fde L, Rappsilber J, Marston AL (2013) Cohesin-dependent association of $\operatorname{scc} 2 / 4$ with the centromere initiates pericentromeric cohesion establishment. Curr Biol 23 (7):599-606. https://doi.org/10.1016/j. cub.2013.02.022

11. Hinshaw SM, Makrantoni V, Kerr A, Marston AL, Harrison SC (2015) Structural evidence for Scc4-dependent localization of cohesin loading. elife 4:e06057. https://doi.org/10. 7554 /eLife. 06057

12. Verzijlbergen KF, Nerusheva OO, Kelly D, Kerr A, Clift D, de Lima Alves F, Rappsilber J, Marston AL (2014) Shugoshin biases chromosomes for biorientation through condensin recruitment to the pericentromere. elife 3 : e01374. https://doi.org/10.7554/eLife. 01374

13. Vincenten N, Kuhl LM, Lam I, Oke A, Kerr AR, Hochwagen A, Fung J, Keeney S, Vader G, Marston AL (2015) The kinetochore prevents centromere-proximal crossover recombination during meiosis. elife 4. https://doi.org/10. 7554 /eLife. 10850

14. Nelson JD, Denisenko O, Bomsztyk K (2006) Protocol for the fast chromatin immunoprecipitation (ChIP) method. Nat Protoc 1 (1):179-185. https://doi.org/10.1038/ nprot.2006.27

15. Cockram CA, Filatenkova M, Danos V, El Karoui M, Leach DR (2015) Quantitative genomic analysis of RecA protein binding during DNA double-strand break repair reveals RecBCD action in vivo. PNAS Aug 25;112 (34):E4735-42.

16. DeAngelis MM, Wang DG, Hawkins TL (1995) Solid-phase reversible immobilization for the isolation of PCR products. Nucleic Acids Res 23(22):4742-4743

17. Ewels P, Magnusson M, Lundin S, Kaller M (2016) MultiQC: summarize analysis results for multiple tools and samples in a single report. Bioinformatics 32(19):3047-3048. https://doi. org/10.1093/bioinformatics/btw354

18. Li H (2018) Minimap2: pairwise alignment for nucleotide sequences. Bioinformatics 34 (18):3094-3100. https://doi.org/10.1093/ bioinformatics/btyl91

19. Li H, Handsaker B, Wysoker A, Fennell T, Ruan J, Homer N, Marth G, Abecasis G, Durbin R, 1000 Genome Project Data Processing Subgroup (2009) The sequence alignment/map format and SAMtools. Bioinformatics 25(16):2078-2079. https:// doi.org/10.1093/bioinformatics/btp352

20. Quinlan AR, Hall IM (2010) BEDTools: a flexible suite of utilities for comparing genomic features. Bioinformatics 26 
(6):841-842. https://doi.org/10.1093/bio informatics/btq033

21. Robinson JT, Thorvaldsdottir H, Winckler W, Guttman M, Lander ES, Getz G, Mesirov JP (2011) Integrative genomics viewer. Nat Biotechnol 29(1):24-26. https://doi.org/10. $1038 /$ nbt. 1754

22. Tian B, Yang J, Brasier AR (2012) Two-step cross-linking for analysis of protein-chromatin interactions. Methods Mol Biol 809:105-120. https://doi.org/10.1007/978-1-61779-3769_7
23. Craig DW, Pearson JV, Szelinger S, Sekar A, Redman M, Corneveaux JJ, Pawlowski TL, Laub T, Nunn G, Stephan DA, Homer N, Huentelman MJ (2008) Identification of genetic variants using bar-coded multiplexed sequencing. Nat Methods 5(10):887-893. https://doi.org/10.1038/nmeth.1251

24. Ford E, Nikopoulou C, Kokkalis A, Thanos D (2014) A method for generating highly multiplexed ChIP-seq libraries. BMC Res Notes 7:312. https://doi.org/10.1186/17560500-7-312

Open Access This chapter is licensed under the terms of the Creative Commons Attribution 4.0 International License (http://creativecommons.org/licenses/by/4.0/), which permits use, sharing, adaptation, distribution and reproduction in any medium or format, as long as you give appropriate credit to the original author(s) and the source, provide a link to the Creative Commons license and indicate if changes were made.

The images or other third party material in this chapter are included in the chapter's Creative Commons license, unless indicated otherwise in a credit line to the material. If material is not included in the chapter's Creative Commons license and your intended use is not permitted by statutory regulation or exceeds the permitted use, you will need to obtain permission directly from the copyright holder. 